\title{
知的財産教育をきっかけとする多様な 学生に対する工学教育の試み
}

Intellectual Property Education to Various Students as Starting Point of Engineering Education

\begin{tabular}{|c|c|c|}
\hline 宏 守※1 & 木 村 友 久*1 & 二 $* 1$ \\
\hline Hiromori TSUTSUMI & Tomohisa KIMURA & Koji MORI \\
\hline Hidetoshi YAMAMOTC & $\begin{array}{c}\text { 原 田 直 幸※1 } \\
\text { Naoyuki HARADA }\end{array}$ & $\begin{array}{l}\text { 小 柏 香穂理 }{ }^{2} \\
\text { Kaori OGASHIWA }\end{array}$ \\
\hline
\end{tabular}

Diversification of the university entrance examinations induces differences of scholastic attainments of the students. It is difficult to maintain various students' learning motivation with interests in basic engineering education courses. We think that the students can be motivated by learning the basic course about the intellectual property. Because the knowledge level of the freshmen about the intellectual property is almost equal to each other. The knowledge about the intellectual property is very important in the industrial offices where the students will work after graduation of university. We report the survey results of the intellectual property education programs for the first-year students. The follow-up survey and some problems of the intellectual property education program are also reported.

Keywords: Engineering Education, Intellectual Property Education, Student, Educative Effect

キーワード : 工学教育, 知的財産教育, 学生, 教育効果

\section{1.まえがき}

高等学校に扔ける理数科目の履修状況の多様化 ${ }^{1)}$ や，AO入試などの導入に伴う入試制度の多様化 ${ }^{2)} に$ より, 同一入学年度の同一学科学生の中でも理数系科 目に対する基礎学力には大きなばらつきが見られる. このような中で, 学生に対して理数科目の基礎的な内 容を初年次教育として集中的に実施することも試みら れているが，学習意欲の惹起という点においては，基 礎科目のみでは難しい点も多い，言い換えると，理数 系科目の学習動機を持たない状態で，高校レベルの基 礎的な内容の学習実施は学生の学習意欲を削ぐ結果を 引き起こす可能性もある. 学力別にクラス分けを行い, 学習内容を工夫する方法により，上述のような問題点 を改善することも可能であるが，人的な余裕が少ない 教育現場では実施困難なことも多い.

そこで我々は，理数系の専門科目に対する学習の動 機付けとして, 知的財産教育を用いることを提唱して きた ${ }^{3)}$.この考えの背後には, 理工系学部卒業生が将

平成 22 年 2 月 17 日受付

※ 1 山口大学大学院

※2山口大学メディア基盤センター
来就く職業は，企業の技術者や研究者が主なものであ り, その現場では, 特許などの知的財産に関する基礎 知識が必要となる。また，実際の製品に用いられてい る数多くの特許を媒介として, 今から学ぶ理数系の基 礎科目や専門科目と実際の企業活動との結びつきを明 確化することによる動機付けも可能になる.もちろん, 通常の専門科目の授業の中で, 教員側が意識して, 実 際の企業活動と現在学んでいる専門科目内容との関連 を説明することは可能ではあるものの，その科目の内 容に対する理解度がクラス内でばらついていることに より実際の講義のレベル設定などに難しい点が残って いる.

これに対して, 知的財産教育を出発点とする工学教 育に対する動機付けの利点は, 以下のように整理でき る.

（1）一部の工業高校などを除いて, 高等学校で知的財 産に関する教育を行っている例は無く，知的財産の 講義開始時には, クラス内の学生の知的財産に関す る知識や理解度は，ほほ同じと考えられる。

(2) 従って知識量や理解度からみた実力差は無く, 一 定のレベル設定を行った教材や講義などで，ほぼ同 じ到達点に至ることができる教育を実施できる. 
（3）皆が同一レベルからスタートするので，通常の科 目では，あまり理解度の高くない学生でも，劣等感 などを持たずに学習による自己能力の伸びを実感し やすい.

以上のような利点を期待して, 我々は学部 1 年生を 対象に知的財産教育を行うことを実施してきた。本論 文では, 学部 1 年生に対して基礎教育の一環として知 的財产教育を行った場合の即効的な効果の検証結果及 び，その教育効果を高次学年まで持続させることの難 しさについて報告するとともに，その点の改善に対す る指針について述べる。

\section{2. 方法}

\section{1 学部 1 年生に対する知的財産教育の実施}

対象は, 本学工学部応用化学科の学生約 90 名 (学年 により人数が異なる), 平成 18 年度入学〜平成 20 年度 入学者を対象とした．各年度の入学生に対して 1 年次 の共通教育として行われる基礎セミナー（前期開講, 2 単位）の中で, 90 分 $\times 3$ コマで講義を行った，講義 内容の概要を表 1 に示す.

第 1 回目は, 知的財産に関する基礎的な語句の解説 を行った後, 知的財産の重要性を取り上げたDVD ${ }^{5)}$ を視聴させ, 視聴内容に関連した感想などを書かせた.

第 2 回目は, 特許電子図書館 (IPDL) や山口大学 特許情報検索システム（YUPASS）を用いた知的財 産に関する情報の検索方法について講述した後, 実際 に検索を行う演習を実施した。

第 3 回目は, 特許明細書の簡単な読み方について解 説を行い, 後半の時間では, 簡単なパテントマップの 見方について，実例を挙げて説明を行った。

各年度の講義や演習の実施は, 毎年の理解度アン ケートなどに基づいて，若干の手直しを加えたり，第 2 回目の特許検索演習については, 使用教室の関係で 十分な演習が行えなかったりした年度もあるが，基本

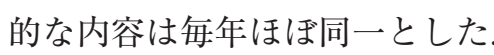

なお，この講義前後における学生の理解度の変化や 関心度の変化に関する調查については, 既報の方法に より行った ${ }^{4)}$. この調査方法は, (1)講義などに出て きたキーワードに対する理解度の変化を講義の前後で 比較調查する方法，(2) 自由記述アンケートに基づい た回答を頻出キーワードにより精查する方法を組み合

表 1 実施した講義・演習の内容など

\begin{tabular}{|c|c|}
\hline & 講義 · 演習内容 \\
\hline 第 1 回 & $\begin{array}{l}\text { 講義（知的財産に関する基礎，知的財産に関連 } \\
\text { したDVD }{ }^{5} \text { をを視聴） }\end{array}$ \\
\hline 第 2 回 & $\begin{array}{l}\text { 講義・特許検索演習（特許電子図書館（IPDL） } \\
\text { などを使用して検索実施） }\end{array}$ \\
\hline 第 3 回 & $\begin{array}{l}\text { 講義・演習（特許明細書を読むための基礎知識, } \\
\text { 細書を読む） }\end{array}$ \\
\hline
\end{tabular}

わせたものである.

\section{2 履修後の追跡調査の実施とその分析}

2.1 で述べた講義を受講した学生における知的財 産などに関する意識の変化や専門科目などの受講に対 する影響について調査を行うために, 履修後の追跡調 査をアンケート形式で行った。 このアンケートは, 主 に 3 つの観点から質問を行った。（1）知的財産教育を 受けたことの有用性について, (2) 知的財産教育で学 んだことと専門科目の内容との関連付けや連携性を意 識しているかどうかについて，(3)特許検索を日常的 に行っているかどうか, についての 3 つの観点で, ア ンケートを行った. アンケートは回答選択形式のアン ケートとし, 履修科目の登録や卒業研究のための配属 研究室決定が終了し比較的落ち着く時期である 6 月に 実施した。

\section{3. 結果と考察}

\section{1 学部 1 年生対象講義の実施結果と課題}

最初に, 知的財産に関する予備知識に入学年度で差 があるかについて確認を行った．新聞やニュースなど で目にしやすい語句や内容を用いて, それについて 知っているかどうかを調查し, 検証に利用した，結果 を表 2 に示す。学年度に依存せず, 特許については 漠然としたイメージを持っていると, ほぼ $80 \%$ 以上の 学生が答えている。 これに対して,「特許制度（権利 期間や審査の仕組みなど）について知っていますか」 という踏み达んだ質問に対しては，毎年70〜80\%の 学生が「あまり知らない」「全く知らない」と答えて おり, 知的財産に関する基礎的な理解は, 入学年度に 依存しないと考えられた。 また, 特許などの権利取得 に関する関心は，約 $80 \%$ 前後と高い值を示しており， この点を講義の導入開始点として用いることで一定の 効果が期待できると予想された.

同様にキーワード理解度の講義前後における変化に ついての入学年度依存性について比較を行ったとこ ろ, 全体的な傾向として, 入学年度による大きな差 は見られなかった ${ }^{4)}$. 以上の点から，この 3 年間に入 学した学生の知的財産に関する基礎知識は差がほぼ無 く, また, 3 回の講義で理解した程度も年度による大 きな差が無いと考えられた。

自由記述回答では，いくつかの観点に立った質問を 行い, それらを解析した。『今後の自分と知的財産(権) との関わりについて，どうしたいか，どう考えている かなどについて書いて下さい（例えば, 就職や自分 の進路との関わりなど)』という質問に対しては, 専 門科目に対する学習意欲が増したとする内容や自らの 将来 - 専門科目 - 知的財産のつながりに言及する内容 が目立った。いくつかの回答を紹介する.

【回答 1】将来, 研究職に就きたいと思っているので 知的財産権とは切っても切れない関係になると思い 
表 2 講義前アンケートの年次変化

\begin{tabular}{|c|c|c|c|c|}
\hline \multirow{2}{*}{ 質問事項 } & \multirow{2}{*}{ 回答 } & 平成18年 & 平成19年 & 平成20年 \\
\hline & & $\%$ & $\%$ & $\%$ \\
\hline \multirow{4}{*}{$\begin{array}{l}\text { ブランド品は法律で保護されている } \\
\text { ことを知っていますか. }\end{array}$} & よく知っている & 8.1 & 16.7 & 17.2 \\
\hline & 大体知っている & 42.4 & 47.6 & 43.0 \\
\hline & あまり知らない & 36.4 & 26.2 & 28.0 \\
\hline & 全く知らない & 13.1 & 9.5 & 11.8 \\
\hline \multirow{4}{*}{$\begin{array}{l}\text { 特許とは, どういうものか知ってい } \\
\text { ますか. }\end{array}$} & よく知っている & 10.1 & 14.3 & 10.8 \\
\hline & 大体知っている & 70.7 & 75.0 & 72.0 \\
\hline & あまり知らない & 17.2 & 10.7 & 16.1 \\
\hline & 全く知らない & 2.0 & 0 & 1.1 \\
\hline \multirow{4}{*}{$\begin{array}{l}\text { 特許制度（権利期間や審査の仕組み } \\
\text { など）について知っていますか. }\end{array}$} & よく知っている & 3.0 & 1.2 & 1.1 \\
\hline & 大体知っている & 20.2 & 20.2 & 14.0 \\
\hline & あまり知らない & 59.6 & 64.3 & 67.7 \\
\hline & 全く知らない & 17.2 & 14.3 & 17.2 \\
\hline \multirow{4}{*}{$\begin{array}{l}\text { 特許を取得してみたいと思ったこと } \\
\text { がありますか }\end{array}$} & アイデア有り & 1.0 & 1.2 & 1.1 \\
\hline & できれば & 43.4 & 42.9 & 39.8 \\
\hline & 少し関心有り & 40.4 & 36.9 & 45.2 \\
\hline & 思わない & 15.2 & 19.0 & 14.0 \\
\hline
\end{tabular}

ます．だからこそ，もっともっとちゃんと知的財産 権について本などを読んだりして勉強したいと思い ます。

【回答 2】私は将来薬学に関連する企業もしくは研究 所に勤めて, 化学の知識を活かせる仕事に就きたい と思っています。そ和過程で新薬製法や新薬の効能 などで特許を請求することがあると思うので，その 時に今回学んだ特許の知識を活かしたいです。, 又, 特許は発明した後の迅速な対処が大事（早く，とに かく早く請求へ) などで, 常に心に銘じておきたい です。まだまだ特許についての知識は少ないので, これからいざ必要になる前に知識を入れておきたい です。そして，特許を取れるための分野の専門知識 (化学及び薬学) をより梁く理解するように努めた いです.

【回答 3】私は, 基礎セミナーで特許について学ぶま で，その実態をあまりよく知らず，何か日常とかけ はなれたところで行われているものだと思い込んで いました．すごく特別なものという意識が大きかっ たのです．しかし今回学ぶにつれて，本当に日常の あちらこちらにあるのだと分かりました。姉に何か 特許の商品を知らないかと聞いたことがありまし た. 私は, 心の中で姉は知らないだろうとばかり思っ ていましたが，姉はすぐに答えました，姉の会社が 特許の商品を持っていたのです，私は本当に驚きま した．知らないのは私の方でした，そして将来出来 たら特許をとってみたいという願望もわきました. どうなるか分かりませんが, 頑張ってみたいと思い ます。

このような例だけでなく，その後の専門科目の動機 付けになったという感想が多くあり, 当初の目的は達
成できたものと考えられる.

また，日常生活の中に知的財産情報と関わりを持つ ようになったという回答もあり, 以下にいくつかを紹 介する。

（a）インターネットをするときyahooのトップペー ジに知的財産権に関する記事があるとチェックす るようになった。

(b) 特許電子図書館をパソコンで見るようになっ た.

(c) 特許は自転車一つにおいても多くの発明があ り, 身近なところでも自分が使っている特許商品 があるのではないかと思った。

（d）今まではニュースなどで特許について話して いてもほとんど興味がなかったけど，これからは もっと特許について関心を媣めたいと思った.

（e）父に特許について詳しく聞いてみたいと思う。

（f）スーパーなどに買い物に行くと, 特許などがあ るかなと思い, 商品の箱を良く見るようになりま した.

(g) 何か調べたい品物とかがあれば, すぐに特許 電子図書館を用いて調べるようになった。

なお，この講義の実施に伴い生じた課題について簡 単に指摘する。(1)講義担当者の確保：本事例の応用 化学科の学生に対する講義は, 担当者の確保の点では 問題はなかったものの, 本取組を他の学科や他学部へ 展開する場合には, 担当者の確保は重要な点となると 考えられる. (2)他の担当者との調整：この講義は, 学部の共通教育科目の基礎セミナー（全15回）の中で 実施したため, 連続した 3 回を確保するために, 日程 調整などが必要であった。この点は, 課題など時間外 学習方法を工夫することで, 連続した 3 回でなくとも, 
学習効果を高めることも可能と考えられ, 講義内容の 見直し等で対応できると考えられる。（3）適切な教材 の準備：市販の知的財産教育に関する書籍は, 法律論 などから入るものが多く, 理工系学生の初歩段階に使 用すると，その時点で学生の興味が失われることも多 い. 我々は，文部科学省現代的教育ニーズ取組支援プ ログラム（現代GP）「理工学系学生向け実戦的知的財 産教育」(平成17年度 19年度) の中で, 理工系学生 の知的財産教育に適した教材開発などを実施し，本講 義でも，これらの教材を利用した。現代GPの中で開 発した教材などは, 提供も可能なので, 実施をお考え の方は著者までご連絡下さい.

\section{2 追跡アンケートの結果と課題}

3.1 で述べた講義を実施した後の追跡調査をアン ケート形式で行った，得られた結果を整理したものを 図 1 から 3 に示す。このアンケートは, 先述したよう に主に3つの視点で行った。

知的財産教育の有用性についての回答（図 1) は,

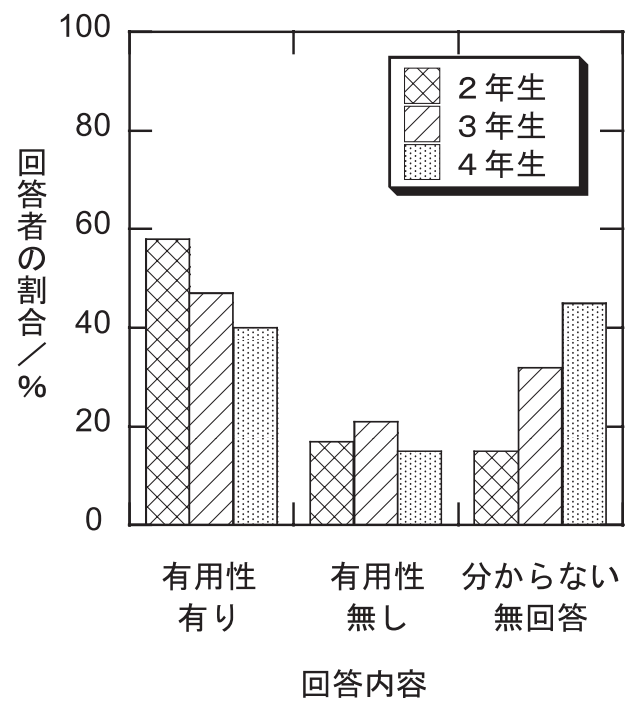

図 1 アンケートの結果（知的財産教育の有用性）

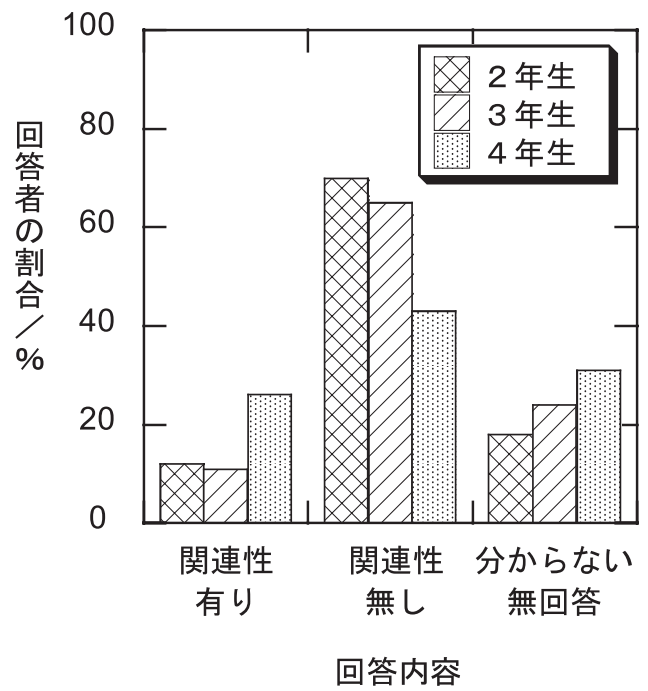

図 2 アンケートの結果 (知的財産教育と専門科目の関連性)
学年進行により, やや肯定的な意見（とても役に立っ たまあ役に立った，どちらかといえば役に立った） は減少するものの, 4 年生においても $40 \%$ を維持して いた。 また，学習後，約 1 年を経過した 2 年生におい ては, この比率は $58 \%$ となっており, 知的財産につい て学んだことの有用性は，この程度の期間では十分に 印象として残っていることが明らかとなった.

次に, 本講義や演習の目指している, 知的財産教育 と専門科目との連携性が専門科目学習のきっかけに なったかどうかについての質問に対する回答（図 2 ) のうち, 肯定的な意見（大変大きなきっかけになった, かなりきっかけになった，まあ,きっかけになった)は, 2 年生においては $11 \%$ 程度だったものが, 4 年生では $26 \%$ となった。また, 関連性無し, と回答する割合は 学年進行とともに減少した。このような傾向を示した 理由は 2 年生では専門科目の基礎的な部分の履修が始 まったばかりであり, 知的財産との連携が感じられな い内容が主になっているためと考えられる。これに対 して, 高学年になると, 専門科目の中に, より応用的 な部分が加わり，製品などに近い技術や材料が話題と なるためにこのような連携性を意識するようになっ たと考えられる，さらに 4 年生になると，卒業論文の 研究が始まり, その研究対象が知的財産と密接に関連 することも多いために，連携性をさらに感じるように なるためと考えられる.

特許検索の日常性についての設問（図 3 ）では, ど の学年においても, $53 \sim 74 \% の$ 学生が, 特許検索を 行っていないことが明らかとなった.これは通常の学 生生活の中で, 特許検索を必要とする場面が少ないた めと考えられる. また, 先ほどの設問の回答とやや矛 盾する結果が 4 年生では得られている。これは, 実際 の卒業研究では, 特許情報を利用する研究室が少ない こととも関連していると考えられる ${ }^{6)}$.この点は, 研

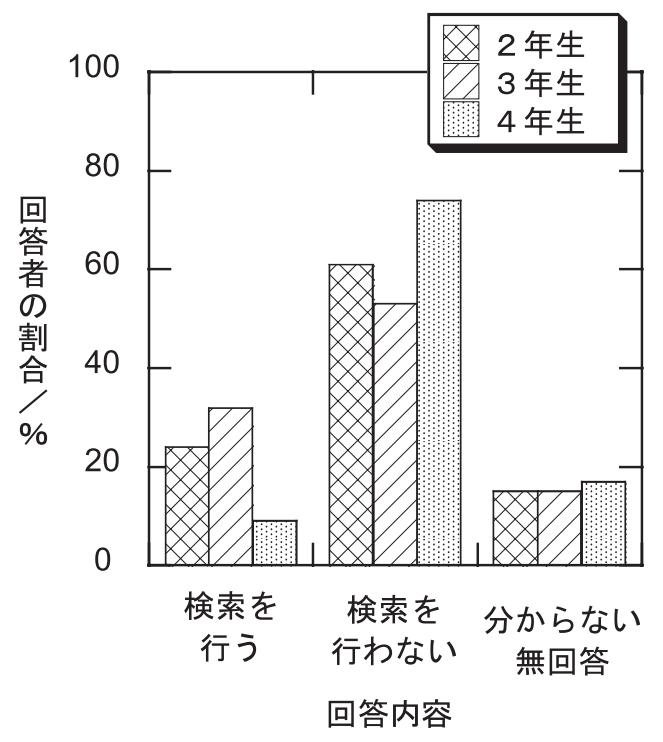

図３アアンケートの結果（特許検索の日常性） 
究分野によっても異なると考えられるが，卒業研究時 の特許情報などの有効活用を学生のみならず，教員層 にも定着を図ることで学生の意識変化が起こるものと 考えられる.

\section{3 問題点の解決に向けての提案と今後の展開}

3.2 で述べたように学部 1 年次における知的財産 に関する教育効果は，学年進行に伴い徐々に薄れてい く傾向が見られた。ここでは，現在我々が取り組んで いる対策について述べる.

特許を意識する指標として IPDLの利用について注 目すると，学部 1 年生の時には，身の回りの製品に使 われている特許を見つけ，IPDLを用いてその明細書 を探す，という課題があるため，商品の箱などをじっ くり見て，検索するという行動をとるようになる。さ らにその延長として，比較的日常生活で気になった製 品などがあるとIPDLで調べてみるようになった，と いった回答が多いのに対して，学年進行に伴い，この ような視点が日常生活から消えIPDLを使用する機会 が急激に減少するということから考えると, 日常的に 知的財産に関する情報に触れることが極めて重要とな る. 従って, 学年進行に伴う知的財産教育の継続性を 保つ方法としては，知的財産教育に関連した科目を高 次学年でも開講するとともに，必修化することが考え られる，本学においては，高次学年に『知的財産権論』 を開講しているものの, 必修化には至っていない。こ れは，担当可能な教員数が限られており，必修とした 場合には，教員に過度な負担となる可能性があること や，単なる必修化では，理工系学生の興味や関心を引 きつけることが困難であり，場合によっては，“知的 財産嫌い”を増やしてしまう危険性も懸念される。

そこで，次のような取り組みを始めつつある.

(1) 知的財産関連科目と専門科目の連携の強化：これ は, 専門科目の講義の中で知的財産に関連した内容 を取り入れる方法が考えられる。

例えば，専門科目の講義の中で取り上げた材料に ついて，特許検索することで，この材料に関する研 究を行っている企業を探したり, 企業別に, その材 料の製法の違いを整理したりすることで，単に材料 の製法を学習するだけでなく，別のルートからの製 法や，現状での課題まで意識させた学習が可能にな ると考えられる．著者らは，このような教材につい ても検討を行っており, 別の機会に紹介したいと考 えている.

（2）知的財産教育用 e-learning 教材の整備・拡充 : 先 述した知的財産教育担当者確保問題の解決方法とし て, 知的財産教育に関する e-learning 教材の整備・ 拡充がある. e-learning 教材により不足部分などの 学習を学生の自主的な取組により補うものである. 本学においても技術経営研究科所属教員の支援によ り, 理工学系学生向けの知的財産教育用 $\mathrm{e}-$-learning
教材の整備, 拡充を行っている.

（3）学士中間論文（プレ卒論）の実施とその中での知 的財産情報などの利用：本学工学部の一部の学科で は， 2 年次後期に学士中間論文を実施している。こ れは, 通常, 4 年生において実施される卒業論文を, 早めに体験することで, 専門科目に対する学習意欲 の向上や学生自身の将来を考える機会を提供するな どの目的を持って実施している。この学士中間論文 の開始時点に扔いて, 先行技術や先行研究の状況把 握にIPDLなどを利用することが行われている。ま た, 応用化学科においても, この学士中間論文の試 行を平成 21 年度より実施しており, その中でも, こ のような取り組みを開始しつつある。ささらに，4年 次の卒業論文に打いても, 従来の学術論文をべース とする既存研究の探索だけではなく, IPDLやYUPASSを用いた特許情報検索を行うことや，検索結 果を分析してパテントマップを作成するというよう な取組を入れつつある。

もちろん，学部 4 年間で知的財産教育が終わるわ けではなく, 大学院教育の科目に知的財産に関する 内容を含めた講義なども必要であるため, 『知的財 産権特論』といった講義を既に開設している。しか しながら, 従来の大学院の講義などの時間も多く, さらに修士論文のための研究 (実験) の時間との兼 ね合いもあり，講義時間数を増やすなどの手法によ る知的財産教育の充実は, 未だ途上の状態にある。

\section{4.あとがき}

学生の知的財産に関する基礎的な知識や，一定時間 で実施した講義の効果に, 入学年度による差が無いこ とが明らかとなった. 講義直後の自由記述回答からは, 専門科目に対する学習意欲が高まったことや, 自分の 将来と専門科目との関連を知的財産教育により認識で きたことが明らかとなった。本論文は, 知的財産教育 が工学教育のきっかけとなりうるかどうかについての 観点からの報告であり, 今後もさらなる検証が必要で あるとともに，今回明らかになった高次学年における 知的財産教育の継続性の維持が大きな課題と考えられ る.

\section{謝辞}

本論文で述べた実証講義や教材開発の一部は, 文部 科学省現代的教育ニーズ取組支援プログラム（現代 GP)「理工学系学生向け実戦的知的財産教育」(平成 17年度〜 19年度）による援助により実施されたもの であり，ここに記して感謝する。

\section{参 考 文 献}

1）例えば, 鈴木 誠, 池田文人, 土岐 均, 湯田恭丈, 和田健夫, 佐藤振一郎, 大山 勉, 苫米地司, 阿部 
和厚, 山岸みどり：大学 1 年生は高校 4 年生?, 高等教育ジャーナル - 高等教育と生涯学習 - , 11, pp. $163-172,2003$

2 )平成 20 年度国公私立大学・短期大学入学者 選抜実施状況の概要 (2008年 9 月26日発表), http://www.mext.go.jp/b_menu/houdou/ 20/09/08092911.htm

3 ) 平成17年度採択山口大学現代GP報告書, 理工系学 生向け実戦的知的財産教育, 2009

4 ) 堤 宏守, 小柏香穂理, 三木俊克 : キーワードと自 由記述アンケートを用いた学習理解度評価システ ムによる教育方法改善, 平成 20 年度工学・工業教 育研究講演会講演論文集, pp.690-691

5 ）プロジェクトX挑戦者たち 第 6 期 突破せよ 最強 特許網 新コピー機 誕生, NHKエンタープライズ
6 ）平成18年度特許庁研究事業, 受託研究報告書 “大 学における研究者用特許情報データベース活用モ デルの構築と検証”, 山口大学, 2007

\section{著 者 紹 介}

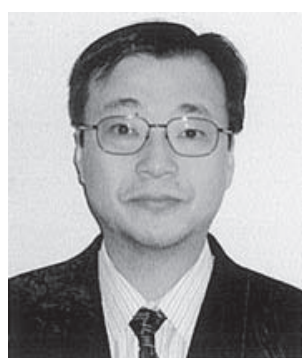

堤 宏守

1985年信州大学大学院繊維学研究科機能 高分子学専攻修了, 1988年大阪大学大学 院工学研究科応用精密化学専攻修了, 工 学博士. 専門は機能高分子化学, 電気化 学 (エネルギー貯蔵デバイス材料), 理工 系学生向け知的財産教育. 所属学会, 日 本化学会, 高分子学会, 表面技術協会, 電気化学会 